\title{
PENGARUH PENERAPAN TEORI VAN HIELE BERBANTUAN SOFTWARE WINGEOM TERHADAP KEMAMPUAN PENALARAN MATEMATIKA SISWA PADA MATERI GEOMETRI
}

\author{
Fitri Amalia Izzati $^{1}$, Hadi Kusmanto ${ }^{2}$, Toheri $^{3}$ \\ Tadris Matematika \\ Institut Agama Islam Negeri (IAIN) Syekh Nurjati Cirebon \\ E-mail: fitriamaliaizzati24@gmail.com ${ }^{\text {l) }}$,hadi_upi@yahoo.com ${ }^{2)}$, htoheri_okt@yahoo.co.id ${ }^{3)}$
}

\begin{abstract}
One of the purpose of mathematics is to develop students' mathematical reasoning abilities. But in the fact indicate that objective can't be realized optimally. This research aims to determine the effect of application Van Hiele theory aided software wingeom to mathematical reasoning ability students on geometry. This research is case study with a sample of 40 students and using technique purposive sampling. The technique of collecting data used questionnaire and essay tests. Based on analysis of questionnaire obtained an average percentage of 63,04\%, that means the student responded strongly. While mathematical reasoning ability is quite an average of 67,25\%. Based on the hypothesis test analysis whit significance 5\% show there is the effect of application Van Hiele theory aided software wingeom to mathematical reasoning ability on geometry. From the regression equation obtained $\hat{Y}=8,482+0,847 X$. The coefficient is positive, that means there is a positive correlation between the application Van Hiele theory aided software Wingeom and mathematical reasoning ability. The coefficient of determination 0,166 meaning that 16\% variable mathematical reasoning ability is determined by the Van Hiele theory aided application software wingeom, while the remaining $84 \%$ is explained by other variable. The application of Van Hiele theory aided Wingeom software significantly affect students' mathematical reasoning ability on geometry.
\end{abstract}

\section{Key words: Van HieleTheory, software, Wingeom, Mathematical reasoning}

\section{PENDAHULUAN}

Pentingnya pelajaran matematika tidak lepas dari peran matematika dalam segala aspek kehidupan oleh karena itu matematika tidak terlepas dari pembelajaran. Pembelajaran adalah upaya sistematis yang terdapat interaksi didalamnya baik itu antara guru dengan siswa, siswa dengan siswa, siswa dengan sumber belajar, sehingga mengarah kepada perubahan tingkah laku siswa sesuai dengan tujuan pembelajaran yang akan dicapai (Jihad, 2008).

Pembelajaran matematika adalah proses interaksi dan komunikasi baik antara guru dengan siswa maupun siswa dengan siswa dalam mempelajari mata pelajaran matematika yang meliputi kegiatan penelusuran pola dan hubungan serta pemecahan masalah, kegiatan menumbuhkan kreativitas, imajinasi dan penemuan serta kegiatan mengkomunikasikan informasi atau gagasan.

Ruseffendi dalam (Suherman, 2003) menyatakan bahwa matematika terbentuk sebagai hasil pemikiran manusia yang berhubungan dengan ide, proses dan penalaran. Mengacu pada pendapat tersebut, penalaran merupakan salah satu aspek penting untuk memperoleh hasil belajar matematika yang baik. Dengan adanya penalaran, siswa dapat merasa yakin bahwa matematika itu dapat dipahami dan dianalisa. Para siswa harus belajar bagaimana cara menemukan kesalahan dalam berpikir. Penalaran matematika tertuang pada salah satu tujuan pembelajaran matematika secara umum dalam Permendiknas No. 22 tahun 2006, yaitu agar siswa dapat menggunakan penalaran pada pola, sifat, melakukan manipulasi matematika dalam membuat generalisasi, menyusun bukti, atau menjelaskan gagasan, dan pernyataan matematika. Penalaran merupakan salah satu aspek kognitif yang dimiliki oleh setiap individu. Penalaran dan matematika merupakan aspek yang saling terkait.

Fakta dilapangan menunjukan kemampuan penalaran matematis siswa di Indonesia masih rendah. Hal ini dapat dilihat dari program BERMUTU (Better Education through Reformed Management and Universal Teacher Upgrading) yang diterbitkan oleh Departemen Pendidikan Nasional tahun 2008 bahwa hasil survei Trends Internasional In Mathematicsand Science Study (TIMSS) pada tahun 2007 menempatkan Indonesia pada peringkat 36 dari 49 negara. Sedangkan pada PISA tahun 2009 Indonesia hanya menduduki ranking 61 dari 65 negara. Berdasarkan hasil studi pendahuluan tanggal 16 Januari 2017 dan wawancara dengan guru mata pelajaran matematika kelas VIII SMP Islamiyah Weru Kabupaten Cirebon diketahui bahwa selama ini siswa memiliki kekurangan dalam hal kemampuan penalaran matematik. 
Hal yang menjadi permasalahan saat proses pembelajaran matematika adalah banyaknya siswa yang berpendapat bahwa matematika merupakan mata pelajaran yang sulit untuk dipahami. Hal ini terjadi karena beberapa siswa hanya sekedar menghapal rumus, lalu mengikuti cara guru menjawab soal, dan bukan menganalisa persoalan yang diberikan. Kesulitan anak dalam belajar matematika terletak pada kegagalannya dalam memahami ide matematika dengan pikirannya sendiri.

Salah satu cabang matematika yang diajarkan di sekolah adalah geometri. Banyak konsep matematika yang dapat diterangkan dengan representasi geometris. Geometri mempunyai peluang yang lebih besar untuk dipahami siswa karena ide-ide geometri sudah dikenal oleh siswa sebelum mereka masuk sekolah, misalnya garis, bidang dan ruang. Akan tetapi diakui oleh guru dan siswa bahwa geometri itu sulit untuk dipelajari, sehingga penalaran siswa pada materi geometri pun rendah. Banyak faktor penyebab rendahnya penalaran siswa dalam geometri. Salah satu diantaranya adalah faktor pembelajaran. Usiskin dalam Ikhsan (2012) mengatakan kualitas dari pengajaran merupakan salah satu faktor yang mempunyai pengaruh paling besar terhadap penalaran siswa dalam geometri

Terdapat beberapa teori yang dapat diterapkan oleh pendidik untuk menyampaikan materinya dalam pembeljaran. Teori pemebelajaran tersebut juga bisa diterapkan pada pembelajaran matematika. Beberapa teori tersebut yaitu: Teori Bandura, Teori Piaget, Teori Bruner, Teori Van Hiele, Teori Frudenthal dan teori-teori lain. Untuk meningkatkan penalaran geometri siswa diperlukan suatu pembelajaran yang sesuai. Salah satu teori pembelajaran yang dapat digunakan adalah teori Van Hiele. Teori Van Hiele inilah yang akan dijadikan orientasi dalam pembelajaran matematika dalam penelitian ini.

Menurut teori Van Hiele seseorang akan melalui lima tahap perkembangan berpikir dalam belajar geometri. Kelima tahap perkembangan berpikir Van Hiele adalah tahap 0 (visualisasi), tahap 1 (analisis), tahap 2 (deduksi informal), tahap 3 (deduksi), dan tahap 4 (rigor)(Sutama, I Ketut, I Gusti Putu Suharta, 2014).

Penggunaan media pemelajaran merupakan salah satu perangkat pemelajaran yang mendukung keberhasilan tercapainya tujuan pembelajaran. Akan tetapi kenyataan di sekolah menunjukkan bahwa kebanyakan guru hanya mengandalkan gambar-gambar bangun ruang statis yang ada pada buku untuk menjelaskan materi geometri kepada siswa. Bangun ruang yang disajikan pada selembar kertas, akan sangat sulit divisualisasikan oleh siswa. Untuk itulah diperlukan media yang mampu membantu siswa memvisualisasikan bangun ruang. Salah satu software yang dapat digunakan dalam pembelajaran geometri adalah program Wingeom.

\section{LANDASAN TEORI}

Penalaran adalah pemikiran yang diadopsi untuk menghasilkan pernyataan dan mencapai kesimpulan pada pemecahan masalah yang tidak selalu didasarkan pada logika formal sehingga tidak terbatas pada bukti (Rosita, 2008). Penalaran yang diungkapkan oleh Keraf adalah proses berpikir yang berusaha menghubung-hubungkan fakta-fakta atau evidensi-evidensi yang diketahui menuju kepada suatu kesimpulan (Shadiq, 2004). Beberapa ahli mengklasifikasikan kemampuan penalaran kedalam beberapa jenis. Menurut (Sumarmo, 2010) secara garis besar penalaran dapat digolongkan dalam dua jenis yaitu Penalaran induktif dan penalaran deduktif. Penalaran induktif adalah penarikan kesimpulan yang bersifat umum atau khusus berdasarkan data yang teramati dengan nilai kebenaran yang bersifat benar atau salah.

Penalaran deduktif adalah penarikan kesimpulan berdasarkan aturan yang disepakati. Nilai kebenaran dalam penalaran deduktif bersifat mutlak benar atau salah dan tidak keduanya bersama-sama.

Berdasarkan pernyataan di atas, secara umum dapat disimpulkan bahwa kemampuan penalaran matematika adalah kemampuan seseorang untuk melakukan kegiatan atau proses berpikir logis dan analitik berdasarkan pernyataan matematika yang telah dipercaya kebenarannya sampai akhirnya didapatkan kesimpulan yang valid baik secara deduktif maupun induktif.

Indikator-indikator penalaran yang harus dicapai oleh siswa menurut Peraturan Dirjen Dikdasmen No. 506/C/PP/2004 (Shadiq, 2009) antara lain adalah:

a) Kemampuan menyajikan pernyataan matematika secara lisan, tertulis, gambar dan diagram

b) Kemampuan mengajukan dugaan

c) Kemampuan melakukan manipulasi matematika 
d) Kemampuan menyusun bukti, memberikan alasan/bukti terhadap kebenaran solusi

e) Kemampuan menarik kesimpulan dari pernyataan

f) Memeriksa kesahihan suatu argument

g) Menemukan pola atau sifat dari gejala matematis untuk membuat generalisasi

Salah satu teori dalam aliran kognitif terdapat teori belajar yang dikemukakan oleh Van Hiele (1954), teori ini menguraikan tahap-tahap perkembangan mental anak dalam geometri. Van Hiele adalah seorang guru bangsa Belanda yang mengadakan penelitian dalam pengajaran geometri (Amir, 2016). Van Hiele (Abdussakir, 2011) mengungkapkan bahwa dalam belajar geometri terdapat lima tahap perkembangan mental peserta didik, yaitu pengenalan, analisi, pengurutan, dedusi, dan keakuratan. Adapun tahap berpikit van hiele dapat dijelaskan sebagai berikut:

1) Tahap 0 (Visualisasi)

Pada tahap ini siswa mengenal bentuk-bentuk geometri hanya sekedar berdasar karakteristik visual dan penampakannya.

2) Tahap 1 (Analisis)

Pada tahap ini sudah tampak adanya analisis terhadap konsep dan sifat-sifatnya. Siswa dapat menentukan sifat-sifat suatu bangun dengan melakukan pengamatan, pengukuran, eksperimen, menggambar dan membuat model.

3) Tahap 2 (Deduksi Informal)

Pada tahap ini, siswa sudah dapat melihat hubungan sifat-sifat pada suatu bangun geometri dan sifat-sifat antara beberapa bangun geometri.

4) Tahap 3 (Deduksi)

Pada tahap ini siswa dapat menyususn bukti, tidak hanya sekedar menerima bukti. Siswa dapat menyusun teorema dalam sistem aksiomatik.

5) Tahap 4 (Rigor)

Pada tahap ini siswa bernalar secara formal dalam sistem matematika dan dapat menganalisis konsekuensi dari manipulasi aksioma dan definisi. Saling keterkaitan antara bentuk yang tidak didefinisikan, aksioma, definisi, teorema dan pembuktian formal dapat dipahami.

Langkah-langkah pembelajaran dengan menerapkan teori van hiele berbantuan software wingeom, yaitu:
Tahap 0 (visualisasi)

1) Fase 1: informasi (information)

Tanya jawab tentang materi sebelumnya disertai dengan Menampilkan gambar bangun geometri beserta unsur-unsurnya tanpa disertai keterangan

2) Fase 2: orientasi langsung (directed orientation)

Siswa menggali langsung informasi yang didapat dari gambar yang ditampilkan

3) Fase 3: penjelasan (explanation)

Memberi penjelasan seminimal mungkin dan menambahkan keterangan pada gambar yang telah ditampilkan sebelumnya

4) Fase 4: orientasi bebas (free orientation)

Siswa diberi tugas sederhana tentang materi yang dibahas, tugas ditampilkan padasoftware wingeom

5) Fase 5: integrasi (integration)

Menampilkan semua gambar yang telah dipelajari sebelumnya dan meringkas materi yang telah dipelajari

Tahap 1 (analisis)

1) Fase 1: informasi (information)

Tanya jawab tentang materi sebelumnya disertai dengan Menampilkan gambar bangun geometri yang telah di jelaskan pada pertemuan sebelumnya

2) Fase 2: orientasi langsung (directed orientation)

Dari gambar yang ditampilkan siswa menggali informasi berupa sifat-sifat dan konsep.

3) Fase 3: penjelasan (explanation)

Memberikan tanda untuk mepermudah siswa dalam menggali sifat-sifat bangun tersebut, contoh memberi tanda pada yang sama pada sudut yang nilainya sama.

4) Fase 4: orientasi bebas (free orientation) Menampilkan gambar yang akan ditugaskan kepada siswa

5) Fase 5: integrasi (integration)

Menampilkan gambar dari awal hingga akhir pertemuan disertai dengan menyimpulkan

Tahap 2 (deduksi informal)

1) Fase 1: informasi (information)

Menampilkan gambar disertai keterangan dan tanda-tanda yang bisa mewakili sifatsifat dari bangun datar atau bangun ruang

2) Fase 2: orientasi langsung (directed orientation) 
Menggali informasi yang lebih mendalam dari gambar yang ditampilkan

3) Fase 3: penjelasan (explanation)

Berdasarkan pengalaman sebelumnya, siswa menyatakan pandangan yang muncul struktur yang diobservasi, untuk membantu siswa menggunakan bahasa yang tepat dan akurat, guru memberi bantuan seminimal mungkin. Hal tersebut berlangsung sampai sistem hubungan pada tahap berpikir ini mulai tampak nyata

4) Fase 4: orientasi bebas (free orientation)

Menampilkan tugas-tugas yang lebih komplek berupa tugas yang memerlukan banyak langkah, tugas-tugas yang dilengkapi dengan banyak cara, dan tugas-tugas open ended. Mereka memperoleh pengalaman dalam menemukan cara mereka sendiri, maupun dalam menyelesaikan tugas-tugas. Melalui orientasi diantara para siswa dalam bidang investigasi, banyak hubungan antara objek-objek yang dipelajari menjadi jelas.

5) Fase 5: integrasi (integration)

Siswa meninjau kembali dan meringkas apa yang telah dipelajari. Guru dapat membantu dalam membuat sintesis ini dengan melengkapi survey secara global terhadap apa yan telah dipelajai siswa. hal ini penting, tapi, kesimpulan ini tidak menunjukan sesuatu yang baru. Pada akhir fase kelima ini siswa mencapai tahap berpikir yang baru.

Program Wingeom merupakan salah satu perangkat lunak komputer matematika dinamik (dynamic mathematics software) untuk topik geometri. Program ini dapat digunakan untuk membantu pembelajaran geometri dan pemecahan masalah geometri. Program Wingeom merupakan program yang dapat diperoleh dan digunakan secara gratis (totally freeware), dengan mengunduh (download) dari website: M. Andy Ruditho. Program Wingeom dibuat oleh Richard Parris. Program ini dijalankan under windows. Salah satu fasilitas yang menarik yang dimiliki program ini adalah fasilitas animasi yang begitu mudah. Misalnya benda-benda dimensi tiga dapat diputar, sehingga visualisainya akan nampak begitu jelas (Rudhito, 2008).

\section{METODOLOGI PENELITIAN}

Penelitian ini menggunak metode kuantitatif yang bersifat studi kasus dengan metode regresi untuk melihat adanya pengaruh penerapan teori Van Hiele berbantuan software wingeom terhadap kemampuan penalaran matematik siswa. adapun desain penelitian yang digunakan adalah "One Shot Case Study"model. "One Shot Case Study" yaitu model pendekatan yang menggunakan satu kali pengumpulan data "suatu saat" (Arikunto, 2006). Dengan pola sebagai berikut:

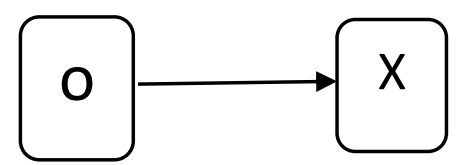

Keterangan :

$\mathrm{X}=$ Treatment yang diberikan (variabel independen)

$\mathrm{O}=$ Hasil observasi sesudah treatment (variabel dependen)

Populasi adalah wilayah yang generalisasi yang terdiri atas objek atau subjek yang mempunyai kuantitas dan karakteristik tertentu yang ditetapkan oleh peneliti untuk dipelajari dan kemudian ditarik kesimpulan (Sugiyono, 2009). Populasi target adalah seluruh siswa-siswi SMP Islamiyah Weru kabupaten Cirebon, sedangkan populasi terjangkau dalam penelitian ini yaitu populasi kelas VIII E dan VIII F.

Berikut tabel populasi terjangkau penelitian ini

Jumlah Siswa Kelas VIII E dan VIII F SMP

Islamiyah Weru Cirebon Tahun Pelajaran 2016/2017

\begin{tabular}{|c|c|c|}
\hline \multirow{2}{*}{ Kelas } & \multicolumn{2}{|c|}{ Jumlah Siswa } \\
\cline { 2 - 3 } & Laki-Laki & Perempuan \\
\hline VIII E & 14 & 16 \\
\hline VIII F & 12 & 18 \\
\hline Jumlah & 26 & 34 \\
\hline
\end{tabular}

Margono menyatakan sampel adalah bagian dari populasi sebagai contoh (master) yang diambil dengan menggunakan cara tertentu (Margono, 2005). Peneliti mengambil subyek sampel sebanyak 2 kelas dari kelas yang ada dengan menggunakan teknik purposive sampling yaitu teknik penentuan sampel dengan pertimbangan tertentu (Sugiyono, 2009). Adapun yang dijadikan sampel adalah siswa kelas VIII E dengan jumlah 20 siswa dan dan kelas VIII $F$ dengan jumlah 20 Siswa, sehingga keseluruhan sampel adalah 40 siswa.

Instrumen yang digunakan dalam penelitian ini meliputi instrumen non tes berupa angket dan tes essay. Angket/kuesioner adalah teknik 
pengumpulan data yang dilakukan dengan cara memberi seperangkat pertanyaan atau pernyataan tertulis kepada responden untuk dijawabnya Sugiyono (2010). Dalam penelitian ini penulis menggunakan angket dengan skala Likert untuk mengetahui data respon siswa terhadap penerapan teori Van Hiele berbantuan software wingeom.

Tes merupakan teknik pengukuran yang di dalamnya terdapat berbagai pertanyaan, pernyataan atau serangkaian tugas yang harus dikerjakan atau dijawab oleh responden (Zainal Arifin 2010). Dalam penelitian ini tes digunakan untuk mengetahui kemampuan penalaran matematika siswa.

\section{HASIL DAN PEMBAHASAN}

Berdasarkan hasil analisis data dari hasil penelitain di lapangan dan pengolahan data yang telah dilakukan oleh peneliti, menyetakan bahwa penerapan teori Van Hiele berbantuan software wingeom pada siswa kelas VIII termasuk ke dalam kategori kuat. Hal ini terlihat dari hasil analisis rata-rata angket respon siswa terhadap penerapan teori Van Hiele berbantuan software wingeom sebesar 69,42, karena nilai dari hasil angket lebih dari 60, respon siswa dapat dikategorikan kuat.

Berdasarkan data angket respon siswa, presentase tertinggi terdapat pada indikator mampu bekerja sama dengan baik dengan temanteman dalam pembelejaran dengan presentase sebesar 80,38\%. Menurut (Riduan dan Sunarto, 2014) indikator tersebut termasuk kategori kuat, sejalan dengan penelitian yang dilakukan Rusyda Amrina dan Karim yang mengukur respon siswa terhadap penerapan teori Van Hiele, hasil presentase rata-rata angket respon siswa adalah sebesar $75,06 \%$ dan termasuk kedalam kategori kuat. Sedangkan presentase terrendah terdapat pada indikator siswa dapat menyimpulkan atau mengevaluasi dengan presentase sebesar 59\%. Menurut (Riduan dan Sunarto, 2014) indikator tersebut termasuk kategori cukup. Berdasarkan taksonomi Bloom evaluasi merupakan Higher Order Thinking Skill (tingkatan tertinggi dalam berpikir). Ranah kognitif menurut taksonomi Bloom terdiri atas enam level, yaitu: knowledge (pengetahuan), (2) comprehension (pemahaman atau persepsi), (3) application (penerapan), (4) analysis (penguraian atau penjabaran), (5) synthesis (pemaduan), dan (6) evaluation (penilaian).

Kemampuan penalaran matematika adalah kemampuan siswa dalam menganalisis berdasarkan konsep atau teori matematika yang telah didapat untuk menemukan kesimpulan yang dianggap benar. Setelah dilakukan analisis terhadap hasil tes kemampuan penalaran matematika yang diberikan kepada 40 siswa kelas VIII E dan VIII F SMP Islamiyah Weru kabupaten Cirebon, didapatkan hasil rata-rata 67,25. Ratarata yang didapatkan menunjukan bahwa kemampuan penalaran matematika pada siswa tersebut tergolong cukup, artinya sebagaian siswa SMP Islamiyah weru memiliki kemampuan penalaran yang cukup. Std. deviasi sebesar 10,85747 menyatakan tingkat variasi data yang telah diperoleh atau ukuran standar penyimpangan reratanya. Nilai variansi sebesar 177,885 menyatakan tingkat penyebaran atau variansi data tinggi. Presentase nilai penalaran tertinggi terdapat pada butir soal nomor 1 yaitu sebesar $80 \%$. Menurut (Arikunto, 2006) kemampuan penalaran matematika siswa pada indikator ini termasuk kategori baik karena rata-rata presentase kemampuan dalam menyajikan pernyataan matematika secara lisan, tertulis, gambar dan diagram sama dengan $80 \%$. Menurut taksonomi Bloom indikator tersebut termasuk kategori pengetahuan, sedangkan kategori pengetahuan merupakan Lower Order Thinking Skills. Sedangkan presentase terendah terdapat pada soal nomor tiga, indikator soal tersebut yaitu kemampuan manipulasi matematika dengan presentase sebesar 54,38\%. Menurut (Arikunto, 2006) kemampuan siswa pada indikator tersebut tergolong cukup. Hal ini karena untuk menyelesaian permasalahan pada indikator ini siswa harus melalui tahap 2 yaitu deduksi informal, pada tahap ini memerlukan tingkat berpikir tinggi. Berdasarkan taksonomi Bloom indikator ini termasuk kategori sintesa yang merupakan higher Order Thinking Skills.

Pada perhitungan statistik untuk analisis data, diawali dengan uji prasyarat analisis yaitu uji normalitas dan uji homogenitas. Pengujian normalitas dalam penelitian ini menggunakan uji Kolmogorov-Smirnov, hasil dari uji normalitas yang dilakukan dengan menggunakan SPSS adalah 0,116. Maka dapat disimpulkan bahwa variable penerapan teori Van Hiele berbantuan software wingeom berdistribusi normal. Uji homogenitas dilakukan dengan menggunakan software SPSS 20.0 dengan taraf signifikansi 0,05. Hasil uji homogenitas yang diperoleh adalah sebesar 0,225. Karena signifikansi lebih dari 0,05 maka dapat disimpulkan bahwa data tersebut bersifat homogen atau data berasal dari populasi yang sama. 
Berdasarkan analisis data yang telah dilakukan, terdapat hubungan yang linear antara penerapan teori Van Hiele berbantuan software wingeom dengan kemampuan penalaran matematika, adapun persamaan yang didapat adalah $\hat{Y}=8,482+0,847 \mathrm{X}$. dari persamaan tersebut kita dapat melihat nilai a $=8,482$ dan nilai $\mathrm{b}=0,847$. Koefisien bernilai positif artinya terdapat hubungan positif antara penerapan teori Van Hiele berbantuan software wingeom dan kemampuan penalaran matematika. Nilai b merupakan nilai koefisien regresi, nilai tersebut menyatakan setiap penambahan (peningkatan) penerapan teori Van Hiele berbantuan software wingeom akan mempengaruhi kemampuan penalaran matematika sebesar 0,847. Selain itu terdapat hubungan yang linear pada penerapan teori Van Hiele berbantuan software wingeom dengan kemampuan penalaran matematika yaitu diperoleh nilai signifikansi sebesar 0,011, karena nilai signifikansinya kurang dari 0,05 .

Koefisien korelasi yang diberikan variabel $\mathrm{X}$ kepada variabel $\mathrm{Y}$ yang dilihat dari nilai $\mathrm{R}$ sebesar 0,40 berdasarkan tabel 3.16 menunjukan bahwa hubungan antara kedua variable yaitu tergolong kategori korelasi rendah. Sedangkan nilai koefisien determinasi ( $\mathrm{R}$ square) sebesar 0,160 artinya $16 \%$ variable kemampuan penalaran matematika ditentukan oleh variable penerapan teori Van Hiele berbantuian software wingeom dan sisanya sebesar $84 \%$ dipengaruhi oleh variabel lain diluar penelitian.

Sealanjutnya dilakukan uji hipotesis terhadap hasil penelitian, dapat dilihat bahwa terdapat pengaruh yang signifikan antara penerapan teori Van Hiele berbantuan software wingeom dengan kemampuan penalaran matematika. Hal ini ditunjukan oleh hasil analisis regresi yaitu nilai $t_{\text {hitung }}=2,691$ dan $t_{\text {tabel }}=2,023$ Maka $\mathrm{H}_{\mathrm{o}}$ ditolak dan $\mathrm{H}_{1}$ diteriama, artinya bahwa terdapat pengaruh yang signifikan antara variable $\mathrm{X}$ (penerapan teori Van Hiele berbantuan software wingeom) terhadap variable $\mathrm{Y}$ (kemampuan penalaran matematika).

Dari penjelasan di atas, peneliti dapat menyimpulkan bahwa penelitian yang dilakuka peneliti dapat memperkuat penelitian-penelitian sebelumnya. Data-daa penelitian menunjukan bahwa penerapan teori Van Hiele berbantuan software wingeom berpengaruh terhadap kemampuan penalaran matematika siswa di kelas VIII E dan VIII F SMP Islamiyah Weru Kabupaten Cirebon, adapun besar pengaruhnya adalah $16 \%$. Sedangkan sissanya yaitu $84 \%$ dipengaruhi oleh faktor lain.

\section{KESIMPULAN DAN SARAN \\ Kesimpulan}

Penerapan teori Van Hiele berbantuan software wingeom pada proses pembelajaran matematika menunjukan respon yang kuat dari siswa. Hal tersebut bisa terlihat dari hasil angket yang telah disebarkan kepada responden yang menjadi sampel penelitian. Angket yang telah disebarkan tersebut berdasarkan kepada 3 (tiga) aspek dan 9 (Sembilan) indikator. Berdasarkan hasil angket tersebut diperoleh presentase rata-rata sebesar 63,04\%.

Kemampuan penalaran matematika siswa setelah dilakukan analisis pada hasil tes yang diberikan kepada 40 siswa kelas VIII SMP Islamiyah Weru kabupaten Cirebon, diperoleh hasil rata-rata nilai siswa adalah 67,25. Berdasarkan rata-rata yang diperoleh menununjukan bahwa kemampuan penalaran matematika pada siswa tersebut dikategorikan cukup.

Berdasarkan analisis uji hipotesis terhadap hasil penelitian, dapat dilihat bahwa terdapat pengaruh yang signifikan antara penerapan teori Van Hiele berbantuan software wingeom dengan kemampuan penalaran matematika ini ditunjukan oleh hasil analisis regresi yaitu nilai $t_{\text {hitung }}=2,691$ dan $\mathrm{t}_{\text {tabel }}=2,023$ juga diperoleh persamaan $\hat{Y}=$ $8,482+0,847 \mathrm{X}$, dari persamaan tersebut kita dapat melihat nilai koefisien regresi sebesar 0,847, nilai tersebut menyatakan setiap penambahan (peningkatan) penerapan teori Van Hiele berbantuan software wingeom akan mempengaruhi kemampuan penalaran matematika sebesar 0,847. Koefisien korelasi yang diberikan variabel $\mathrm{X}$ kepada variabel $\mathrm{Y}$ yang dilihat dari nilai $\mathrm{R}$ sebesar 0,40 menunjukan bahwa hubungan antara kedua variable tergolong kategori korelasi rendah. Sedangkan nilai koefisien determinasi ( $\mathrm{R}$ square) sebesar 0,160 artinya $16 \%$ variable kemampuan penalaran matematika ditentukan oleh variable penerapan teori Van Hiele berbantuian software wingeom dan sisanya dipengaruhi oleh variabel lain diluar penelitian.

\section{Saran}

Menggunakan dan memanfaatkan media maupun sumber belajar yang relevan sehingga kegiatan belajar mengajar dapat mencapai tujuan pembelajaran dengan maksimal. Penerapan teori Van Hiele berbantuan software wingeom pada 
materi lingkaran kurang tepat digunakan karena berdasarkan uji kebaikan model menunjukan variable $\mathrm{X}$ memberikan kontrobusi yang kecil terhadap varianel Y. Penggunaan software wingeom lebih baik bila diterapkan pada materi bangun ruang seperti kubus, balok, limas, prisma, bola, dll karena salah satu kelebihan dari software wingeom adalah bangun ruang yang ditampilkan dapat diputar-putar atau dianimasikan.

Perlu dikaji tentang faktor-faktor yang dapat mempengaruhi kemampuan penalaran matematika selain penerapan teori van hiele berbantuan software wingeom seperti yang telah dibahas penulis pada skripsi ini, seperti kebiasaan belajar, sikap ilmiah, metode pembelajaran yang digunakan oleh guru pada saat proses pembelahaan, media pembelajaran, dll.

\section{DAFTAR PUSTAKA}

Abdussakir. (2011). Pembelajaran Geometri Sesuai Teori Van Hiele. Kependidikan Dan Keagamaan, 2.

Amir, Z. R. (2016). Psikologi Pembelajaran Matematika. Yogyakarta: aswaja Presindo.

Arifin, Z. (2010). Metodologi Penelitian Pendidikan Filosofi, Teori dan Aplikasinya. Surabaya: Lentera Cendikia.

Arikunto, S. (2006). Prosedur Penelitian Suatu Pendekatan Praktek. Jakarta: Rineka Cipta.

Ikhsan, M. (2012). Pengembangan Model Pembelajaran Berbasis Teori Van Hiele untuk Meningkatkan Kemampuan Geometri Siswa SMP di Kota Banda Aceh, 17, 164172.

Jihad, A. (2008). Pengembangan Kurikulum Matematika. Yogyakarta: Multi Pressindo.

Kumaidi, \& Manfaat, B. (2013). Pengantar Metode Statistika Teori dan Terapannya dalam Penelitian Bidang Pendidikan dan Psikologi.

Margono. (2005). Metodologi Penelitian Pendidikan. Jakarta: Rineka Cipta.

Riduan dan Sunarto. (2014). Pengantar Statistik. Bandung: Alfabeta.

Rosita, C. D. (2008). Kemampuan penalaran dan Komunikasi Matematis: Apa, Mengapa, dan Bagaimana Ditingatkan pada Mahasiswa (Vol. 1).
Rudhito, M. A. (2008). Geometri dengan Wingeom Panduan dan Ide Belajar Geometri dengan Komputer. Yogyakarta.

Shadiq, F. (2004). . Penalaran, Pemecahan Masalah, dan Komunikasi dalam Pembelajaran Matematika.: Yogyakarta: PPPG Matematika.

Sugiyono. (2009). Statistika Untuk Penelitian. Bandung: Alfabeta.

Sugiyono. (2010). Metode Penelitian Pendidikan. Bandung: Alfabeta.

Suherman, E. dkk. (2003). Strategi Pembelajaran Matematika Kontemporer. Bandung: UPI.

Sumarmo. (2010). Berpikir dan Disposisi Matematik: Apa, Mengapa, dan Bagaimana Dikembangkan Pada Peserta Didik.

Sutama, I Ketut, I Gusti Putu Suharta, G. S. (2014). Pengembangan Perangkat Pembelajaran Geometri SMA Berdasarkan Teori Van Hiele Berbantuan Wingeom dalam Upaya Meningkatkan Aktivitas dan Hasil Belajar Siswa, 3(1). 